\title{
A new finding of a uniquely large population of Anacamptis morio (Orchidaceae) on the Left-Bank Ukraine
}

\author{
Vasyl L. Shevchyk ${ }^{1}$, Igor V. Solomakha ${ }^{2}$, Oksana V. Shevchyk ${ }^{1}$, \\ Tetyana S. Dvirna ${ }^{3 *}$, Volodymyr A. Solomakha ${ }^{4}$, \\ Taras V. Shevchyk ${ }^{1}$ \& Tetyana V. Fitsailo ${ }^{3}$
}

${ }^{1}$ Taras Shevchenko National University of Kyiv, NSC Institute of Biology and Medicine, Hlushkova Avenue 2, 03127 Kyiv, Ukraine; ORCID: VLS - http://orcid.org/0000-0002-3696-1968, TVS - http://orcid.org/0000-0001-6898-8623

${ }^{2}$ Institute of Agroecology and Environmental Management of National Academy of Agrarian Sciences of Ukraine, Mikhail Omelyanovich-Pavlenko 9, 01010 Kyiv, Ukraine; IVS - http://orcid.org/0000-0001-8853-2973

${ }^{3}$ M. G. Kholodny Institute of Botany, National Academy of Sciences of Ukraine, Tereshchenkivska 2, 01601 Kyiv, Ukraine; TSD - http:// orcid.org/0000-0002-9279-9766

${ }^{4}$ Vasyl' Stus Donetsk National University, 600-Richchya 21, 21000 Vinnytsya, Ukraine; VAS - http://orcid.org/0000-0003-3975-5366

*corresponding author (e-mail: dvirna_t@ukr.net)

\begin{abstract}
The paper presents the results of the research of local population of Anacamptis morio (L.) R. M. Bateman on the territory of the Left-Bank Ukraine. The size of this population was estimated at about 250-300 thousand individuals. The average density of individuals per $1 \mathrm{~m}^{2}$ is 12 , while in terms of age structure, dominate individuals in the generative stage (70$75 \%$ ). A. morio inhabits fresh, forest-meadow biotopes. Its populations are found in fresh eutrophic and moist mesotrophic meadows and in coastal floodplain forests. This species is a part of vegetation of the Koelerio-Corynephoretea and MolinioArrhenatheretea classes. Considering the characteristics of the investigated $A$. morio population and its habitat we assert that the studied territory is unique, valuable and perspective for the creation of a nature reserve.
\end{abstract}

Key words: vulnerable species, orchid, new location, ecological scales, biodiversity protection, Ukraine

\section{Introduction}

The studied species was first described by C. Linnaeus in 1753 from Europe and called Orchis morio L. In 1997, R. M. Bateman, A. M. Pridgeon and M. W. Chase reclassified it according to new molecularphylogenetic data and moved to the genus Anacamptis Rich. (Bateman et al. 1997). A. morio is widespread throughout Europe, its range covers Scandinavia, Central and Atlantic Europe and the Mediterranean Region (Sobko 1989; Evans 2011; Gaponenko \& Ivannikov 2013; Stroh 2014; Paušič \& Kaligarič 2015). However, over the past decades, it has become a critically endangered species. Populations of this plant have become almost extinct in Austria and Central Europe (Jersakova et al. 2002; Jacquemyn et al. 2005; Kull \& Hutchings 2006; El-Heliebi 2015). It also has an international protected status under the Convention on International Trade in Endangered Species of Wild Fauna and Flora - its status is near threatened (CITES 1973, 2017; Anacamptis 2011; Stroh 2014). In Ukraine, this species occurs at the eastern boundary of its range and is categorized as vulnerable. It is distributed in the Carpathian region (Gorgany, Volcanic Carpathians, Chyvchyny, 
Chornohora), Roztochhya-Opillya, Southern Polissya and Forest-Steppe natural zone, and the Crimea). The plants grow in moderately damp meadows, on mountain meadow slopes with southern and southwestern exposures, and rarely in the grassy forest clearings and at the forest edges (Protopopova \& Orlov 2009; Gaponenko \& Ivannikov 2013). Due to the species rarity, the negative tendencies in the dynamics of many of its populations and the threat of their disappearance, A. morio was regularly included in the lists of all editions of the Red Data Book of Ukraine (Sytnik 1980; Didukh 1996, 2009).

The status of the protected species, first of all, determines the need for the most complete information on $A$. morio distribution, phytocoenotic role and condition of its populations in the area of Ukraine. This is especially true for these populations that are isolated in separate regions. The purpose of our work was a comprehensive study of the local population of $A$. morio.

\section{Study area}

A new area of $A$. morio occurrence was found between the villages of Tyshky and Vysachky in the Lubny district of Poltava region (Figs. 1-2). It is located on the left bank part of the Uday River, in the terraced floodplains between the rivers Uday and Sulytsya (tributaries of Sula). This area extends in a sub-latitudinal direction and has the triangle-like shape, with an acute angle in the west.

The area of the study has the shape of an irregular oval, narrowed in latitudinal and elongated in the longitudinal directions. Its approximate boundary coordinates are indicated for the boundary points according to the data from Google maps (https://www.google.com.ua/ maps/preview). The central point of this area has the following coordinates: $50.112003 \mathrm{~N}$ and $33.144376 \mathrm{E}$.

The studied territory belongs to the IchnyanskoLokhvytskyi physiographic region situated within the North Prydniprovsk lowland of the Left-Bank Pridneprovsky region (Popov et al. 1968). It is a terraced lowland that is slightly raised and divided by the rivers Sula and Uday. Most of the interfluve surfaces of this area lie between 150 and $190 \mathrm{~m}$ a.s.l. (Marinych \& Shishchenko 2005). Within the watershed, the basement bottom is uneven and covered with diluvial loam, modern alluvial and lacustrine-alluvial sandy loam and ancient alluvial sandy sediments (Vernander \& Tyutyunnik 1986).

The climate of this area is subcontinental. The sum of active temperatures above $10^{\circ}$ is $2600-2800^{\circ}$, aver-

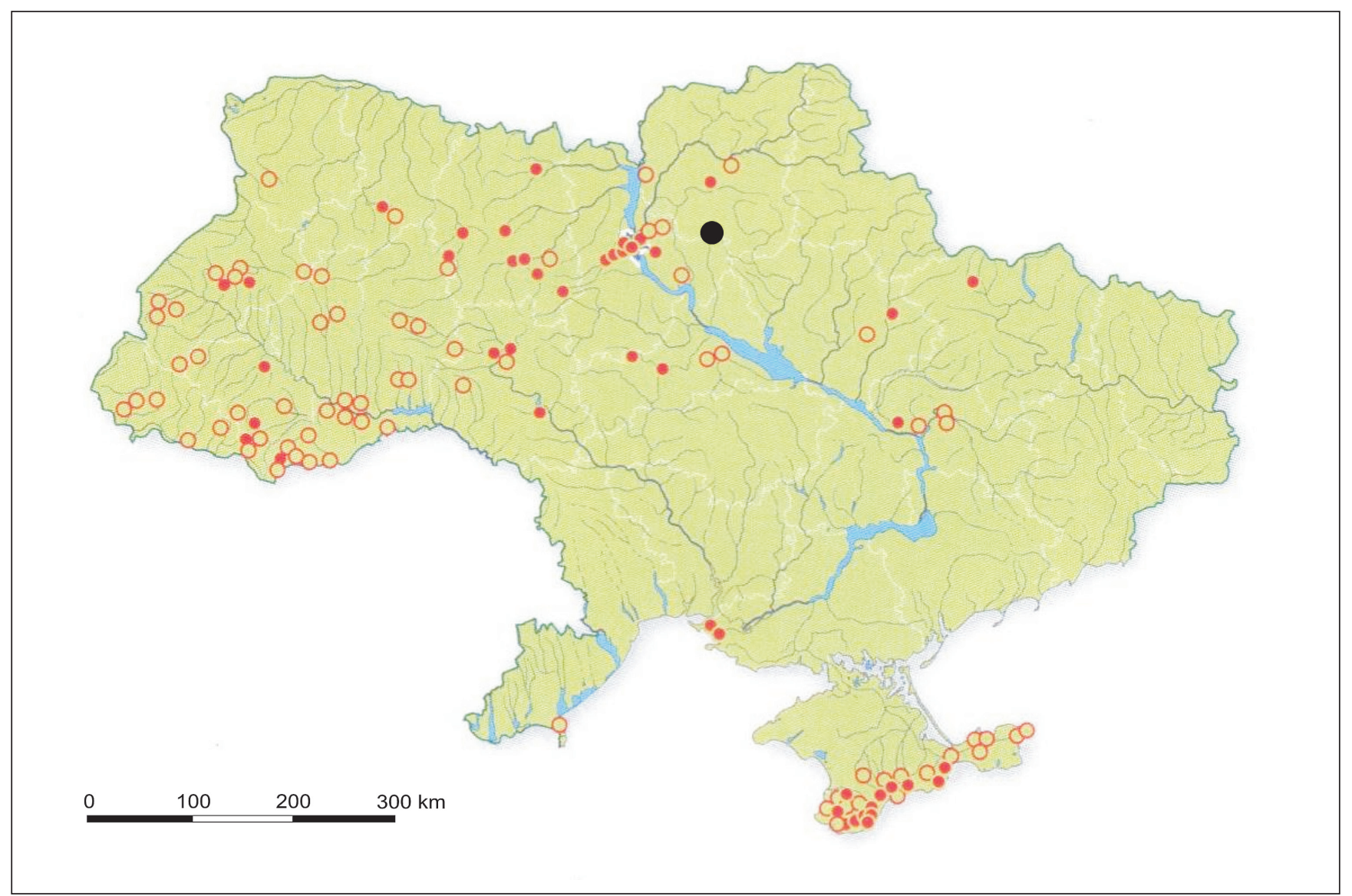

Fig. 1. The distribution of Anacamptis morio in Ukraine and location of its newly discovered locality 


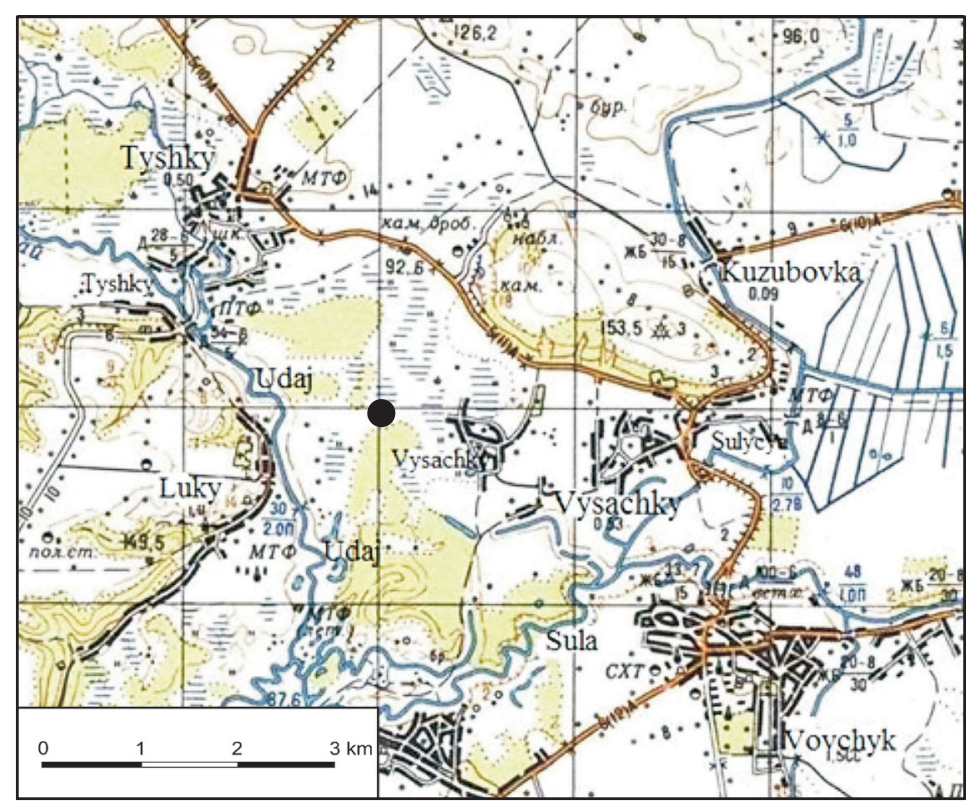

Fig. 2. The location of the studied area

age annual precipitation is $500-550 \mathrm{~mm}$, while effective rainfall is $210-220 \mathrm{~mm}$ (Logvinov \& Shcherban 1984).

The surface of the studied flood plain is elevated about 92-97 m a.s.1. Dominating soil types comprise meadow-peat and peaty soils. The depth of groundwater is determined by the level of surface runoff and mostly ranges from $0.5-1.5 \mathrm{~m}$.

Vegetation is represented by the spectrum of different grassland and swampy meadow communities and, to a lower degree, by forests and wetland forests. Wet and marshy meadows and thickets of coastal vegetation are distributed along the ancient oxbow landforms (Solomakha 2008). In this area dominate such associations as: Caricetum gracilis Almquist 1929, Caricetum acutiformis Sauer 1937, and Phragmitetum communis (Game 1927) Schmale 1939, while shrub and forest vegetation occur only fragmentarily. In particular, communities representing the classes: Alnetea glutinosae Br.-B1. et Tx. ex Westhoff et al. 1946 and Franguletea Doing ex Westhoff in Westhoff et Den Held 1969, can be found scattered everywhere. The forest communities of Salicetea purpureae Moor 1958 occur in the areas with strongly varying water supply (Solomakha 2008).

\section{Material and methods}

The object of our research is a new locality of Anacamptis morio, which was discovered on 10.05.2018 during the routine floristic and geobotanical surveys of the floodplain located at the confluence of the Uday and Sula rivers. Space images from the Google Earth Pro database were used to determine this location. GPScoordinates of the studied population were removed when the Status GPS program was used.
In addition, in 2018, the herbarium collections of the National Herbarium of Ukraine (KW), Taras Shevchenko National University of Kyiv (KWU) and The Poltava Museum of Local Lore named after Vasyl Krichevsky (PW) were critically reviewed. Reference materials on the distribution of this species and characteristics of its localities are summarized.

Using conventional field and relevé methods, we have completed full geobotanical description of the discovered locality. Investigations were performed in the standard plots of $4 \times 4 \mathrm{~m}$ and covered all best developed variants of $A$. morio phytocoenoses in an area of about 2 hectares. Coenotic relationships of the species were analyzed based on the principles of the BraunBlanquet school (Braun-Blanquet 1964; Solomakha 2008).

The following indicators of 12 ecofactors according to the scale developed by Didukh \& Plyuta (1994) and Didukh (2011), were estimated: soil humidity (Hd $=23$ marks), soil humidity variation $(\mathrm{fH}=11)$, soil aeration $(\mathrm{Ae}=15)$, content of nitrogen $(\mathrm{Nt}=11)$, soil acid regime $(\mathrm{Rc}=15)$, salt regime $(\mathrm{Sl}=19)$, carbonate content $(\mathrm{Ca}=13)$, thermoregime $(\mathrm{Tm}=17)$, ombroregime $(\mathrm{Om}=23)$, cryoregime $(\mathrm{Cr}=15)$, continentality $(\mathrm{Kn}=17)$, insolation in coenosis $(\mathrm{Lc}=9)$. Unlike the scales of Ellenberg et al. (1992) and Landolt (1977), these indicators do not reflect mean quantities but their ranges (max-min), however, for the further calculations, we took the mean values for all species present in the studied coenosis along with the degree of their participation ( 1 mark - up to $1 \% ; 2-1-5 \% ; 3-5-20 \%$; $4-21-50 \% ; 5-51-100 \%)$.

The relevés are stored in the TURBOVEG database and integrated with the database of ecological scales 
ECODID. This allowed us to use the synphytoindication analysis and apply a range of different mathematical methods. Moreover, on the basis of calculations of indicator values for every releve according to the scale of Didukh (2011) and using the STATISTICA 8 program (StatSoft Inc 2005), we created the graphical diagrams «box-and-whiskers plots» for every ecological scale.

The names of the species are used according to the nomenclatural checklist of Mosyakin and Fedoronchuk (1999).

\section{Results}

\subsection{Location and size of the population}

In terms of environmental protection, the vegetation of the studied grassland meadow, is of particularly great value. The grassland occupies a wavy relief area with the elevation differences ranging from $0.5-1 \mathrm{~m}$. In this area we found a locality of a rare and protected plant species - Anacamptis morio, from the family Orchidaceae. According to the latest data, it is one of six currently existing localities of this species on the

Table 1. Data herbarium labels for the Anacamptis morio specimens from the territory of Ukraine

\begin{tabular}{|c|c|c|c|c|}
\hline No & Date of collection & Place of collection & Habitat characteristics & Collector \\
\hline 1 & 19.04 .1908 & Southern coast of the Crimea, Livadiya & $?$ & Sovins'kyy \\
\hline 2 & 2.05 .1931 & Crimea, Hurzuf & $?$ & $?$ \\
\hline 3 & 6.05 .1915 & Opposite of Novosilky village & $\begin{array}{l}\text { In the meadow, in the valley } \\
\text { of the Irpin' river }\end{array}$ & Semenkevych \\
\hline 4 & 13.05.1916 & Boyars'k forestry, Kladovaya tract & $\begin{array}{l}\text { in damp meadow in the } \\
\text { valley of the Irpin' river }\end{array}$ & Semenkevych \\
\hline 5 & 21.08.1916 & Kiev, ravine near the Kyrylivs'k monastery & 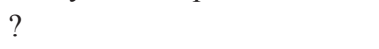 & Semenkevych \\
\hline 6 & 18.05 .1922 & Kiev, Babyy ravine & on the wet slope & Semenkevych \\
\hline 7 & 28.05 .1924 & Cherkasy District, Vynohrads'k monastery & forest meadows & Kleopov \\
\hline 8 & 15.05 .1923 & $\begin{array}{l}\text { Budyshcha village, Zvenyhorods'k district in } \\
\text { the Kyiv region }\end{array}$ & on dry soil & $?$ \\
\hline 9 & 8.05.1931, & Kurylivs'kyy Forest near Kiev & $\begin{array}{l}\text { shore in the forest } \\
\text { in a ravine, on a damp } \\
\text { ground }\end{array}$ & $\begin{array}{l}\text { Hryn', Kosykh, } \\
\text { Mykhaylychenko }\end{array}$ \\
\hline 10 & 7.06 .1932 & $\begin{array}{l}\text { Zhytomyr region, outskirts of Sloboda- } \\
\text { Chernets'ka village }\end{array}$ & Damp hayland & Kozachenko \\
\hline 11 & 28.07 .1933 & $\begin{array}{l}\text { Vinnytsya region, Stanislavs'k district, Budky } \\
\text { village }\end{array}$ & on meadows in ravine & Kleopov \\
\hline 12 & 11.05 .1936 & $\begin{array}{l}\text { Zhytomyr region, Korostyshivs'kyy district, } \\
\text { Synhayi village, near farmstead }\end{array}$ & on meadows & Nakonechnaya \\
\hline 13 & 20.05 .1995 & $\begin{array}{l}\text { Ukraine, Crimea region, Bakhchysaray } \\
\text { district, Samokhvalivka village }\end{array}$ & among the shrubs & $\begin{array}{l}\text { Barbarych, } \\
\text { Dobrochayeva }\end{array}$ \\
\hline 14 & 17.05 .1961 & $\begin{array}{l}\text { Zhytomyr region, Novohrad-Volyns'kyy } \\
\text { district, Striyeva village }\end{array}$ & meadow & Zaverukha, Smolko \\
\hline 15 & 22.05 .1965 & Volyn', Rivne region, Vyshneva hora & $?$ & Kuz'mychov \\
\hline 16 & 29.05 .1974 & $\begin{array}{l}\text { Crimea, by the Feodosiya-Sudak highway, } \\
\text { near the pass }\end{array}$ & $?$ & $?$ \\
\hline 17 & 30.05 .1974 & $\begin{array}{l}\text { Crimea, Heneral's'ke village, on the Karaby- } \\
\text { Yayla plateau }\end{array}$ & near the source & $?$ \\
\hline 18 & 10.05.1979 & Chernihiv region, Nizhyn & $?$ & $?$ \\
\hline 19 & 25.08 .1998 & $\begin{array}{l}\text { Crimea, Kerch Peninsula, outskirts of } \\
\text { Kurortne village }\end{array}$ & $\begin{array}{l}\text { steppe areas along the Azov } \\
\text { Sea }\end{array}$ & Dubovyk \\
\hline 20 & 27.05.1999 & $\begin{array}{l}\text { Bukovyna Cis-Carpathian Region, Chernivtsi } \\
\text { region, outskirts of Budenets'village, } \\
\text { Budenets' forestry, quarter } 19\end{array}$ & meadow & Tokaryuk \\
\hline 21 & 13.05.2000 & $\begin{array}{l}\text { Zhytomyr region, Korostyshiv district, } \\
\text { outskirts of Strutsivka, Zhovtneve forestry, } \\
\text { quarter } 49 \text { and } 36\end{array}$ & meadow & Yakushenko, Orlov \\
\hline 22 & $?$ & $\begin{array}{l}\text { Zhytomyr region, Zhytomyr state forests } \\
\text { household, Bohuns'k forestry, quarter } 75\end{array}$ & $\begin{array}{l}\text { peaty meadow, about } 50 \\
\text { individuals of } A \text {. morio }\end{array}$ & Orlov \\
\hline 23 & 11.05.2002 & Outskirts of Bohuns'k forestry & on the meadow & Orlov \\
\hline 24 & 5.05 .2004 & $\begin{array}{l}\text { Bukovyna Cis-Carpathian Region, Chernivtsi } \\
\text { region, outskirts of Turyatko village, Turyats'k } \\
\text { forestry }\end{array}$ & meadow & $?$ \\
\hline 25 & 3.05 .2004 & $\begin{array}{l}\text { Bukovyna Cis-Carpathian Region, Chernivtsi } \\
\text { region, outskirts of Volya village }\end{array}$ & meadow & $\begin{array}{l}\text { Chorney, Tokaryuk } \\
\text { Kuz'myna }\end{array}$ \\
\hline
\end{tabular}


Box Plot of multiple variables

Spreadsheet $12 v^{*} 50$

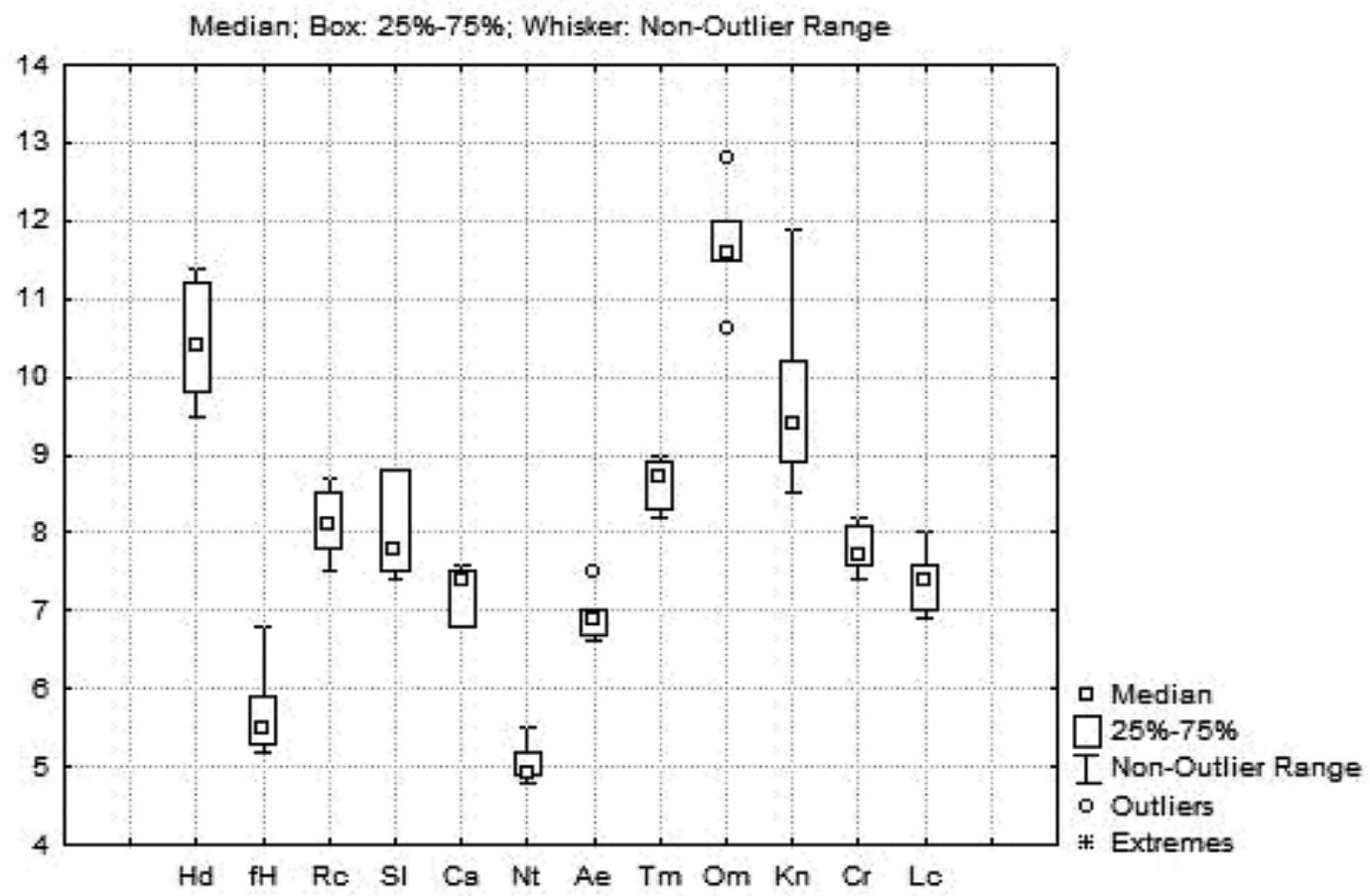

Fig. 3. Ecological indicators for a new locality of Anacamptis morio in the Left-Bank Ukraine

Explanations: $\mathrm{Hd}$ - soil humidity, $\mathrm{fH}$ - soil humidity variation, $\mathrm{Rc}$ - soil acid regime, $\mathrm{Sl}$ - salt regime, $\mathrm{Ca}$ - carbonate content, $\mathrm{Nt}$ - content of nitrogen, $\mathrm{Ae}$ - soil aeration, $\mathrm{Tm}$ - thermoregime, $\mathrm{Om}$ - ombroregime, $\mathrm{Kn}$ - continentality, $\mathrm{Cr}$ - cryoregime, $\mathrm{Lc}$ - light availability

Left Bank of the Dnieper River in Ukraine that has not been described and mentioned in literature before. The total area of the studied locality is about 2 hectares. The average density is 12 individuals per $\mathrm{m}^{2}$ (density ranges from 1-32 individuals per $\mathrm{m}^{2}$ ). The size of this population was estimated at about 250-300 thousand individuals. In the research plots, we noted plants both in generative (70-75\%) and pregenerative (25-30\%) stages, which indicates a high potential for population restoration.

According to the latest research (Hornemann et al. 2012), even residual populations of $A$. morio have a demographically stable character, but the presence of grazing is necessary for their survival, because this species does not tolerate shading by overgrown grasses and woody species.

\subsection{Habitat characteristics}

We collected and analyzed literature data (Solomakha 2008; Mucina et al. 2016) and data from different herbaria to find information on the types of habitats occupied by A. morio (Table 1). The whole set of data clearly characterizes $A$. morio as a species of open spaces, but growing in different edaphotopes. Most collectors indicated the species preference for wet and damp conditions. However, it was also found in dry soil.
Indicator values, calculated using the synphytoindication method, made it possible to determine the range of ecological conditions favourable for $A$. morio (Fig. 3). This species prefers fresh, forest-meadow biotopes with moderately aerated dry clay or wet sandy soils, differentiated wetness of rhizosphere with slightly acidic ( $\mathrm{pH} 5.5-6.5)$ soils, enriched in salt (150$200 \mathrm{mg} / \mathrm{l}$ ), insignificant content of carbonates, relatively poor in mineral nitrogen $(0.2-0.3 \%)$, from semi-shaded to fully sunlit sites, subarid air and semi-continental climate with moderate winter type.

Comparing the obtained indicator values from the studied area with the general amplitude of values for other Ukrainian species (Fig. 3) (Didukh 2011), we can note the relatively narrow ranges of indicator values in the studied locality. These values are in the extreme sections of the species ecological amplitude in relation to a number of factors, such as: soil humidity, variability in soil moisture, aeration of soil, general salt regime, air humidity, continentalism, and cryoregime. The above description indicates the extreme ecological conditions of the study area for $A$. morio, primarily, in relation to the soil water content and humidity of the climate. It is possible that a fluctuating level of soil water content affects the density of A. morio individuals not directly, but due to competition with other herbs, more successful in these conditions. 


\subsection{Synecological characteristics}

The highest number of $A$. morio individuals was found in the plots dominated by densely tufted graminoids and taproot plants. According to our descriptions (Table 2), these groups of species are identified as belonging to the class Koelerio-Corynephoretea Klika in Klika et Novák 1941 (Fig. 4). Within the surveyed areas of $A$. morio occurrence, the associations of species and general nature of vegetation in these habitats were similar, which eliminated the need for a large number of descriptions. According to our two descriptions, these phytocoenoses have not been identified to the syntaxons of lower level; so we predefine them as a derivative of Pilosella officinarum group community.

Table 2. Species composition of vegetation with A. morio in a new locality in the Left-Bank Ukraine

\begin{tabular}{|c|c|c|c|c|c|c|}
\hline \multirow[t]{2}{*}{ Class } & \multirow[b]{2}{*}{ Relevé number } & \multicolumn{2}{|c|}{$\begin{array}{c}\text { Koelerio- } \\
\text { Corynephoretea } \\
\text { group com. Pilosella } \\
\text { officinarum }\end{array}$} & \multicolumn{3}{|c|}{$\begin{array}{c}\text { Festuco valesiacae-Agrostietum } \\
\text { vinealis }\end{array}$} \\
\hline & & 1 & 3 & 2 & 4 & 5 \\
\hline & Plant cover $[\%]$ & 80 & 80 & 70 & 90 & 80 \\
\hline FES & Anacamptis morio (L.) R. M. Bateman & 15 & 20 & 5 & + & 1 \\
\hline COR & Pilosella officinarum Vaill. & 40 & 15 & . & 3 & . \\
\hline COR & Potentilla incana Borkh. & 3 & 30 & . & . & . \\
\hline COR & Veronica verna $\mathrm{L}$. & 2 & + & . & . & . \\
\hline COR & Draba verna $\mathrm{L}$. & 1 & + & + & + & . \\
\hline COR & Poa bulbosa L. & + & + & . & . & . \\
\hline COR & Myosotis stricta Roem. \& Schult. & + & + & + & + & . \\
\hline COR & Helichrysum arenarium (L.) Moench & . & 5 & . & . & . \\
\hline COR & Rumex acetosella $\mathrm{L}$. & . & + & . & . & . \\
\hline COR & Cerastium pumilum Curtis & + & . & 3 & . & . \\
\hline MOL & Carex hirta $\mathrm{L}$. & + & + & . & + & 3 \\
\hline MOL & Achillea millefolium $\mathrm{L}$. & . & . & 5 & 3 & 5 \\
\hline MOL & Plantago lanceolata $\mathrm{L}$. & 2 & + & 10 & 1 & 3 \\
\hline MOL & Lotus corniculatus L. & . & . & 5 & + & 3 \\
\hline MOL & Polygala vulgaris $\mathrm{L}$. & . & . & + & . & + \\
\hline MOL & Stellaria graminea $\mathrm{L}$. & . & . & + & + & . \\
\hline MOL & Ranunculus acris L. & . & . & + & + & 1 \\
\hline MOL & Carex praecox Schreb. & . & . & . & 10 & . \\
\hline MOL & Veronica chamaedrys L. & . & . & . & . & + \\
\hline MOL & Centaurea jacea $\mathrm{L}$. & . & . & . & . & + \\
\hline MOL & Viola persicifolia Schreber & . & . & . & . & + \\
\hline MOL & Trifolium pratense $\mathrm{L}$. & . & . & . & . & 1 \\
\hline MOL & Trifolium montanum $\mathrm{L}$. & . & . & . & . & 1 \\
\hline FES & Potentilla argentea $\mathrm{L}$. & + & + & . & 10 & . \\
\hline FES & Galium verum $\mathrm{L}$. & 3 & + & 5 & 60 & 5 \\
\hline FES & Festuca valesiaca Schleich. ex Gaudin & 10 & + & 3 & + & + \\
\hline FES & Veronica prostrata $\mathrm{L}$. & + & . & 1 & . & 1 \\
\hline FES & Luzula campestris (L.) DC. & . & . & 5 & 5 & 5 \\
\hline FES & Pimpinella saxifraga $\mathrm{L}$. & . & . & 2 & + & + \\
\hline FES & Artemisia marchalliana Spreng. & . & + & . & . & . \\
\hline FES & Brachythecium albicans (Hedw.) Schimp. & . & + & . & . & . \\
\hline FES & Filipendula vulgaris Moench & . & . & . & . & 35 \\
\hline FES & Hypericum perforatum $\mathrm{L}$. & 1 & . & . & . & . \\
\hline FES & Pilosella cymosa (L.) F.W.Schultz \& Sch. Bip. & + & . & + & . & . \\
\hline FES & Eryngium planum $\mathrm{L}$. & . & . & 5 & . & . \\
\hline FES & Gypsophila paniculata $\mathrm{L}$. & + & . & . & . & . \\
\hline FES & Festuca rupicola Heuff. & . & . & . & . & 5 \\
\hline PYR & Centaurea borysthenica Gruner & + & . & . & . & . \\
\hline ART & Poa compressa $\mathrm{L}$. & + & + & + & . & . \\
\hline GER & Silene nutans L. & + & . & + & . & . \\
\hline
\end{tabular}

Explanations: the coverage of species is indicated in percentage, + coverage less than $1 \%$; FES - Festuco-Brometea, COR -Corynephoretea, MOL - MolinioArrhenatheretea, PYR - Pyrolo-Pinetea, ART - Artemisietea, GER - Trifolio-Geranietea 


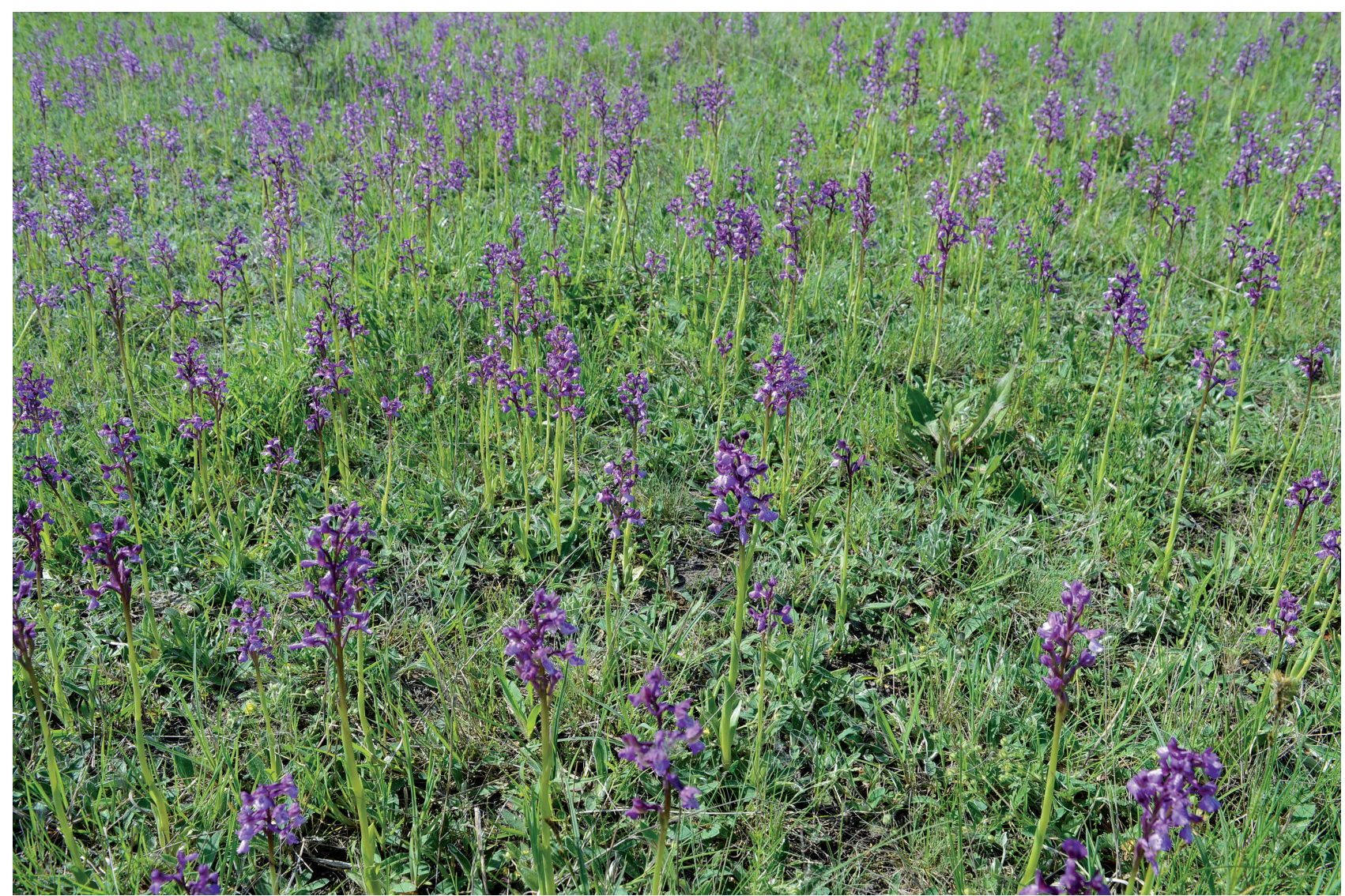

Fig. 4. Koelerio-Corynephoretea grassland inhabited by Anacamptis morio near the villages of Tyshky and Vysachky (photograph by Igor V. Solomakha)

A much smaller number of $A$. morio individuals grew in groups that were identified as the class MolinioArrhenatheretea R.Tx. 1937, order Galietalia veri Mirkin \& Naumova 1986, alliance Agrostion vinealis Sipaylova, Mirkin, Shelyag \& V.Solomakha 1985, association Festuco valesiacae-Agrostietum vinealis Shelyag, Sipaylova, V.Solomakha \& Mirkin in Shelyag et al. 1985. According to the soil mechanical composition and richness, the occupied biotopes did not differ considerably from the previously discussed ones. These biotopes are located in small depressions and probably can be briefly flooded during the flood season or heavy rainstorms. This determines the difference between them and the worst conditions for the survival of the orchid. It should be noted that in the studied plot, there were visible signs of irregular cattle grazing in the past years. In particular, this was proved by the presence of creeping herbaceous plants with a significant participation of grazing-resistant species and herbage mosaic caused by a response to herbivore pressure. Currently, the vegetation of this meadow is in a state of dynamic change due to the cessation of grazing.

The analysis of literature data and herbaria specimens shows the approximate phytocoenotic range of this species within the ecologically-dynamic range of classes: Koelerio-Corynephoretea and Festuco-
Brometea to Molinio-Arrhenatheretea, and the initial stages of afforestation, with a coenotic optimum within the communities of the classes Koelerio-Corynephoretea and Festuco-Brometea.

\section{Discussion: environmental protection recommendations}

The discovered locality of $A$. morio together with the landscape and vegetation complex of this territory are valuable and promising for the creation of the protected area. Currently, this area is unique for the Left-Bank part of the Forest-Steppe zone due to the high density and number of individuals in the population of this protected species.

The studied population of $A$. morio is characterised by high indicators of vitality, presence of individuals of different age groups, the high number of individuals and occurrence of slightly different coenopopulations that occupy large areas. This population can be a good model object in the studies of $A$. morio in situ and an example of the appropriate biotopes for artificial reproduction of populations of this species based on the developed reproduction methods in ex situ conditions (Gaponenko \& Ivannikov 2013). Some of our findings bring more clarity in the discussion concerning phytocoenology 
of this species and its relation to the soil moisture, especially under the flooding conditions.

To determine the threat status of $A$. morio, the occurrence of its populations in the protected areas, such as nature reserves and national parks, should be considered. Thus, according to literature data, the species occurs (or occurred) in some biosphere (BR) and nature (NR) reserves, such as: Carpathians BR - a rarely encountered species of dry meadows of the Pryslop Pass of Uholsko-Shyrokoluzhansky Massive, Solonoozerna area of the Black Sea BR (in meadows), Karadah NR - a single locality (up to 30 individuals), in open areas on the mountains of Small and Great Chuchel in the Crimea NR, Kremenets Mountains NP, Medobory NP, and Cape Martyan NR (Onyshchenko \& Andrienko 2012a). In the latter, the species has not been seen for the past 35 years.

A. morio has been also reported from the following national nature parks (NNP): Biloberezhzhya Svyatoslava NNP - a rare species of meadows, Vyzhnytskyi NNP - small populations found in meadows (in the areas of Sukhyi and Buka and in the mountain valleys of the Bankiv and Kurik ranges), Halytskyi NNP occasionally grows in open areas of Halych and Kosova mountains, Hutsulshchyna NNP - in dry meadows and at the ridge of Karmatura range and on Bryenka tract, Dzharylhatskyi NNP - very rarely in phytocoenoses of the plains of flooded geocomplexes, Dnistrovskyi Canyon NNP, Zacharovanyi kray NNP - in meadows, marshy meadows, glades and forest edges, Oleshkivski Pisky NNP - rare in the meadows of Burkutski Plavni, Pivnichne Podillya NNP - found in the old herbarium collections from the Lysa Mountain near Chervone in the Zolochivskyi district, Synevir NNP - rarely found in the meadows of the forest belt, Skolivski Beskydy NNP - in glades and at forest edges, Uzhanskyi NNP - in meadows (Onyshchenko \& Andrienko 2012b).

The analysis of above data shows more or less proper protection of this species in the protected areas belonging to the nature reserve fund, in the Right-Bank and southern and south-eastern regions of Ukraine and a complete absence of such areas in the central, northern and northeastern regions. In this regard, the area of A. morio that was described by us, has a great value from the nature conservation-oriented point of view, thanks to the unique natural complex of vegetation. Conditions prevailing in this area secure a good prospect of long term survival of the described population of A. morio - a species that has an international protection status and is protected in Ukraine. Diversity of ecotopic habitat conditions demonstrates the urgent need to preserve this area. Extreme indicators of water supply and variability of soil moisture and humidity of the climate are determinative for the survival of the studied population of this rare species. Another important factor is the presence of plant communities representing the appropriate stages of succession, in which A. morio has a modern phytocoenotic optimum, and the presence of moderate grazing that prevents the growth of forests and probably contributes to the creation of stations for seed reproduction of this species.

Furthermore, there are some areas of significant importance for maintaining the biogeocoenic diversity of different habitat types in the region that must be protected in accordance with the Habitat Directive (Council Directive 92\43) and Revised Annex I of Resolution 4 (1996) of the Bern Convention (revised in 2010), using the EUNIS habitat classification. These areas comprise: E2.1 - fresh eutrophic and moist mesotrophic meadows dominated by Alopecurus pratensis L., Poa pratensis L., Carex praecox Schreb., Calamagrostis epigeios (L.) Roth, Equisetum arvense L., and G1.1112+G1.1114 - coastal floodplain forests with the domination of Salix alba L. and thickets of S. cinerea L. (Didukh et al. 2011). Thus, it is advisable to create a protected area in the discussed territory, located in the Lubny district. We have scientifically substantiated the feasibility of its creation. For effective protection of the described natural-territorial complex, it is necessary to prevent the overgrowth of meadow-steppe slopes by shrubs and forest, to take into consideration the need for hand-mowing and moderate grazing, to prevent the possibility of trampling the area by unorganized tourists and large construction works in the above mentioned territory.

In accordance with the current Law of Ukraine 'On the Nature Reserve Fund', the most appropriate protection category for the discussed area will be a botanical reserve of local importance. Due to the representation of environmentally important components (rare species of plants and animals, protected types of biocoenoses) and landscape differentiation (various floodplain areas), this natural reserve area will be a significant addition to the ecological network of Poltava region.

In conclusion, we propose the following activities should be prohibited in the territory of a future reserve: (1) all types of reclamation works, which violate the hydrological regime of the territory; (2) plowing of the land and its reforestation; (3) provision of area for construction; (4) development of mineral resources; (5) use and storage of pesticides; (6) contamination and pollution of the reserve and placement of landfills; (7) motor vehicle traffic outside the roads of general use, with the exception of official and technical transport of land-users and fire-fighting equipment; (8) other types of economic activity that can lead to the loss of natural and scientific value of the proposed reserve and to the destruction of $A$. morio populations.

It is advisable to allow the use of meadows for manual mowing and moderate grazing. It is also im- 
portant to remove self-seeding trees and shrub species in the places of $A$. morio growth.

Acknowledgements. The authors would like to thank the anonymous reviewers and Prof. UAM dr hab. Zbigniew Celka for helpful comments and assistance in preparing the manuscript.

\section{Author Contributions}

Research concept and design: V. L. Shevchyk, I. V. Solomakha, O. V. Shevchyk, V. A. Solomakha
Acquisition and/or assembly of data: V. L. Shevchyk, I. V. Solomakha, V. A. Solomakha

Data analysis and interpretation: O. V. Shevchyk, T. V. Shevchyk, T. V. Fitsailo

Drafting the article: T. S. Dvirna, T. V. Shevchyk, T. V. Fitsailo Critical revision: V. L. Shevchyk, I. V. Solomakha, T. S. Dvirna, V. A. Solomakha

Final approval: T. S. Dvirna

\section{References}

Anacamptis 2011. Anacamptis morio (L.) R. M. Bateman. Species list: Redlist gb post2001-near-threatened. Electronic resource. Access mode: https://species.nb natlas.org/species/NHMSYS0000455893

Bateman R. M., Pridgeon A. M. \& Chase M. W. 1997. Phylogenetics of subtribe Orchidinae (Orchidoideae, Orchidaceae) based on nuclear ITS sequences. 2. Infrageneric relationships and taxonomic revision to achieve monophyly of Orchis sensu stricto. Lindleyana 12: 113-141.

Braun-Blanguet J. 1964. Pflanzensoziologie. Grundzüge der Vegetationskunde. 3rd ed. Springer, Wien, New York.

CITES 1973. Convention on International Trade in Endangered species of Wild Fauna and Flora. Text of the Convention, 27. U.N.T. S. 243.

CITES 2017. Anacamptis morio (L.) R. M. Bateman. Checklist of CITES Species. Electronic resource. Access mode: http://checklist.cites.org/

Didukh YA. P. \& Plyuta P. H. 1994. Phytindication of ecological factors. 280 pp. Naukova Dumka, Kyiv.

DidukH Ya. P. (ed.). 1996. Red Data Book of Ukraine. Plants. 603 pp. Ukrainian Encyclopedia, Kyiv (in Ukrainian).

Didukn Ya. P. (ed.), 2009. Red Data Book of Ukraine. Plants. 912 pp. Globalconsulting, Kyiv (in Ukrainian).

Didukn Ya. P. 2011. The ecological scales for the species of Ukrainian flora and their use in synphytoindication. 176 pp. Phytosociocentre, Kyiv.

Didukh Ya. P., Fitsailo T. V., Korotchenko I. A., Iakushenko D. M. \& Pashrevych N. A. 2011. Biotopes of Forest and Forest-Steppe zones of Ukraine. 288 pp. Kiev.

El-Heliebi S. 2015. Zur Reproduktionsbiologie von Anacamptis (Orchis) coriophora - Bestäubung, Fortpflanzungssystem und Bestandsentwicklung des Wanzenknabenkrauts in der Lobau im Nationalpark Donau-Auen. Master Diploma Thesis - Institut für Integrative Naturschutzforschung, BOKU-Universität für Bodenkultur, pp 116. Vienna.

Ellenberg H., Weber H. E., Düll R., Wirth W., Werner W. \& Paulissen D. 1992. Zeigerwerte von Pflanzen in Mitteleuropa. 2nd ed. Scripta Geobot. 18: 1-258.

Evans K. 2011. Wild orchids of SE England. Report. 62 pp.

Gaponenko M. B. \& Ivannikov R. V. 2013. Prospects of cultivation of Anacamptis morio (L.) R. M. Bateman,
Pridgeon et M.W. Chase (Orchidaceae) for conservation in Ukraine. Ukr Bot J 70(5): 635-641.

Hornemann G., Michalski S. G. \& Durka W. 2012. Shortterm fitness and long-term population trends in the orchid Anacamptis morio. Plant Ecol. 213: 1583-1595.

Jacquemyn H., Brys R., Hermy M. \& Willems J. H. 2005. Does nectar reward affect rarity and extinction probabilities of orchid species? An assessment using historical records from Belgium and the Netherlands. Biol Conserv 121: 257.

Jersakova J., Kindlanan P. \& Stritesky M. 2002. Population dynamics of Orchis morio in the Czech Republic under human influence. In: P. Kindlanan, J. H. Willems \& D. F. Whigham (eds.). Trends and fluctuations and underlying mechanisms in terrestrial orchid populations, 224-299 pp. Backhuys, Leiden.

Kull T. \& Hutchings M. J. 2006. A comparative analysis of decline in the distribution ranges of orchid species in Estonia and the United Kingdom. Biol Conserv 129: 31 .

LANDOLt E. 1977. Ëkologische Zeigerwerte zur schweizer Flora. Veröff. Geobot. Inst. Der Eidgen Techn. Hochschule in Zürich 48: 1-208.

Logvinov K. T. \& ShCHERBAn M. I. (eds.). 1984. The Nature of the Ukrainian SSR. Climate. 232 pp. Science opinion, Kyiv (in Ukrainian).

Marinych O. M. \& Shishchenko P. G. 2005. Physical geography of Ukraine. 511 pp. Kyiv.

MosYakin S.L. \& FedoronchuK N. M. 1999. Vascular plants of Ukraine. A nomenclatural checklist. xxiii +345 pp. Institute of Botany, NAS of Ukraine, Kiev.

Mucina L., Bültmann H., Dierssen K., Theurillat J.-P., Raus T., Čarni A., Šumberová K., Willner W., Dengler J., Gavilán García R., Chytrý M., Hájek M., Di Pietro R., Iakushenko D., Pallas J., Daniëls F. J. A., Bergmeier E., Santos Guerra A., Ermakov N., Valachovič M., Schaminée J. H. J., Lysenko T., Didukh Y. P., Pignatti S., Rodwell J. S., Capelo J., Weber H. E., Solomeshch A., Dimopoulos P., Aguiar C., Hennekens S. M. \& TichÝ L. 2016. Vegetation of Europe: hierarchical floristic classification system of vascular plant, bryophyte, lichen, and algal communities. J Veget Sci 19: 1-783. 
Onyshchenko V. A. \& Andrienko T. L. (eds.). 2012a. Phytodiversity of nature reserves and national nature parks of Ukraine. P.1. Biosphere reserves. Nature reserves. 406 pp. Phytosociocentre, Kyiv (in Ukrainian).

Onyshchenko V. A. \& Andrienko T. L. (eds.). 2012b. Phytodiversity of nature reserves and national nature parks of Ukraine. P.2. National nature parks. 580 pp. Phytosociocentre, Kyiv (in Ukrainian).

Paušič I. \& Kaligarič M. 2015. Dry grassland land use treatment regime explains the occurrence of the green winged orchid, Anacamptis morio (L.) R. M. Bateman, Pridgeon et M.W. Chase in the Goričko Nature Park, Ne Slovenia. Folia Biologica et Geologica 56/3: 138-148.

Popov V. P., Marinich A. M. \& Lanko A. I. (eds.). 1968. Physico-geographical zoning of the Ukrainian SSR. Soil. 678 pp. Kyiv (in Ukrainian).
Protopopova V. V. \& Orlov O. O. 2009. Anacamptis morio (L.) R. M. Bateman. In: Ya. P. Didukh (ed.). Red Data Book of Ukraine. Plants, 154 p. Globalconsulting, Kyiv (in Ukrainian).

Soвко V. G. 1989. Orchids of Ukraine. 192 pp. Naukova Dumka, Kyiv (in Ukrainian).

Solomakha V. A. 2008: The syntaxonomy of vegetation of the Ukraine. The third approximation. 296 pp. Phytosociocentre, Kyiv (in Ukrainian).

Sтroн P. A. 2014. Anacamptis morio (L.) Bateman, Pridgeon $\&$ Chase. Green-winged Orchid. Species account. Botanical Society of Britain \& Ireland.

SYTNIK K. (ed.). 1980. Red Data Book of USSR. 504 pp. Naukova dumka, Kyiv (in Ukrainian).

Vernander N. B. \& Tyutyunnik D. A. (eds.). 1986. The Nature of the Ukrainian SSR. Soils. 216 pp. Kyiv (in Ukrainian). 